\title{
Unit Optimalization Using the QM App for Windows on Perumahan Bukit Aradiar Permai Balikpapan
}

\author{
Oryza Lhara Sari ${ }^{1}$, Andika Ade Indra Saputra ${ }^{1}$, Rosa Gallica ${ }^{1}$, Naila Anisa Dwigida Aprilla ${ }^{1}$ \\ ${ }^{1}$ Civil Engineering and Planning Department, Institut Teknologi Kalimantan, Balikpapan \\ Email: "oryza@lecturer.itk.ac.id, andika@lecturer.itk.ac.id, 07161079@student.itk.ac.id, \\ 07171058@student.itk.ac.id
}

Received: 2021-10-03; Received in revised from 2021-10-19; Accepted: 2021-12-13

\begin{abstract}
Abstrak
Permintaan perumahan terus meningkat seiring dengan pertambahan aktivitas ekonomi dan jumlah penduduk di Kota Balikpapan berdasarkan Badan Pusat Statistik 2017 sebanyak 636.012 jiwa menjadi 645.727 jiwa. Peningkatan permintaan perumahan didorong oleh cara pandang masyarakat bahwa kepemilikan rumah harus dipenuhi sementara ketersediaan rumah terbatas. Berdasarkan Pemerintah Kota Balikpapan dalam Rencana Tata Ruang Wilayah Tahun 2012, rencana pengembangan pola ruang kawasan budidaya lebih banyak mengarah ke bagian utara dan timur kota agar pertumbuhan dan perkembangan penduduk tidak terkonsentrasi di pusat kota. Hal ini merupakan sebuah tantangan bagi penyedia perumahan untuk memenuhi kebutuhan masyarakat yang telah menetap lama maupun masyarakat pendatang dengan membangun perumahan yang berada di Timur Kota Balikpapan sebagai tempat tinggal. Kenaikan harga lahan yang begitu tinggi di Balikpapan diakibatkan adanya perpindahan ibu Kota dari Jakarta menuju Kalimantan Timur, membuat harga jual perumahan juga semakin tinggi. Keterbatasan lahan yang dimiliki pengembang perumahan harus dimanfaatkan sebaik-baiknya untuk pembangunan unit rumah, pembangunan fasilitas, dan adanya ruang hijau di perumahan tersebut sesuai peraturan pemerintahan terkait RTRW Kota Balikpapan. Lahan yang dimiliki pengembang perumahan yang bervariasi bentuknya sangatlah terbatas dengan tipe rumah yang dibangun juga bervariasi dan harga unit yang ditawarkan pun berbeda tiap unitnya. Untuk itu, pengembang harus dapat mengoptimalkan produksi tipe rumah yang akan dibangun berdasarkan ketetapan pemerintah dan Rencana Tata Ruang Wilayah Nasional, pengoptimalan lahan agar mendapatkan keuntungan optimum. Pengoptimalan ini menggunakan aplikasi bantu yaitu QM for Windows dan didapatkan 98 unit untuk tipe 40/120 dan tipe 45/120 sebanyak 102 unit dengan keuntungan optimum menghasilkan Rp 104,292,098,201 untuk metode BEP.
\end{abstract}

Kata Kunci: Optimalisasi; QM For Windows; Unit

\begin{abstract}
Housing demand continues to increase along with the increase in economic activity and the number of residents in the city of Balikpapan according to the 2017 Central Statistics Agency as many as 636,012 people to 645,727 people. The increase in housing demand is driven by the community's perspective that home ownership must be met while housing availability is limited. Based on the Balikpapan City Government in the 2012 Regional Spatial Plan, the plan to develop a spatial pattern of cultivation areas is more directed towards the north and east parts of the city so that population growth and development are not concentrated in the city center. This is a challenge for housing providers to meet the needs of long-lived communities and migrant communities by building housing located in the East of Balikpapan City as a place to live. The increase in land prices is so high in Balikpapan due to the movement of the capital from Jakarta to East Kalimantan, making housing prices also higher. The limited land owned by the housing developer must be utilized as well as possible for the construction of housing units, construction of facilities, and the existence of green space in the housing according to government regulations related to Balikpapan City RTRW. Land owned by housing developers that vary in shape is extremely limited with the type of house being built also varies and the price of the unit offered is different
\end{abstract}


for each unit. For this reason, the developer must be able to optimize the production of the type of house that will be built based on government regulations and the National Spatial Plan, optimizing the land to get the optimum profit. This optimization uses the assistive application of QM for Windows and obtained 98 units for type 40/120 and type 45/120 for 102 units with optimum profit yielding Rp 104,292,098,201 for the BEP method.

Keywords: Optimization; QM For Windows; Unit.

\section{Introduction}

The implementation of housing is carried out based on the community's need for residential housing where Balikpapan's population growth continued to increase in 2017 as many as 636,012 people to 645,727 in 2018 based on BPS City of Balikpapan and also the rate of economic growth which resulted in housing also increasing based on the Ministry of National Development Planning of the Republic of Indonesia. This is a challenge for housing providers to meet the needs of people who have lived for a long time as well as immigrant communities by building housing in the East of Balikpapan City as a place to live.

The increase in land prices is so high in Balikpapan due to the movement of the capital city from Jakarta to East Kalimantan, making the selling price of housing also higher. The limited land owned by housing developers must be utilized as well as possible for the construction of housing units, construction of facilities, and the existence of green space in the housing in accordance with government regulations related to the Spatial Plan of Balikpapan City. For this reason, developers must be able to optimize the production of the type of house to be built based on government regulations and the National Spatial Plan, optimize land in order to obtain optimum benefits and consider other factors such as land area limits, production costs, and market share. So that land optimization is carried out in the Bukit Aradiar Permai residential Balikpapan on type 40/120 with a selling price of Rp. 510,000,000 and type 45/120 with a selling price of Rp. 530,000,000 using the $\mathrm{QM}$ for Windows application.

\section{Method}

Optimization is one of the techniques in operations research that can allocate resources to achieve the goal of maximizing profits based on the determination of the boundary function and the objective function which are summarized in the following equation. The objective function is used to maximize profits, namely the selling price of housing per unit. The constraint function is divided into 5 parts, namely: (a) the effective land area limitation where the coefficient is the land for each type of housing available based on the housing development plan; (b) the limitation of people's purchasing power where the coefficient is the number of people who are estimated to be able to buy a house from the price that has been offered; (c) limitation of consumer interest where the coefficient is the percentage of people's interest in Balikpapan City; (d) limits on the availability of capital for the construction of houses in the first year where the coefficient is the capital for the first year of housing; and (e) the implementation time limit where the coefficient is the length of time it takes to build 1 house of each type available.

After determining the objective and constraint functions, the next step is to determine the number of units and the optimum profit using the QM for Windows program: [9] as follows: (a) open the QM app for Windows; (b) click the "Module" menu and select "Linear Programming"; (c) click "File" then select "New"; (d) the "Create Data Set for Linear Programming" dialog window will appear; (e) in the title column, fill in the title of the analysis; (f) the column "Number of variables" shows the number of variables that make up the equation. In this study there are two variables, namely the variable for the number of types $40 / 120$ and the number of types $45 / 120$, then enter the number 2 ; (g) the column "Number of constraints" shows the number of constraints or constraints that exist. On 
In this study, there are 4 predetermined limits, so enter the number 4; and (h) the "Objective" column is marked with "Maximize" then click "OK"

\begin{tabular}{l|r|r|r|r|r}
\hline & Optimalisasi Perumahan Bukit Aradiar Permai \\
\hline & X1 & X2 & & RHS & Equation form \\
\hline Maximize & 0 & 0 & & & Max \\
\hline Constraint 1 & 0 & 0 & $<=$ & 0 & $<=0$ \\
\hline Constraint 2 & 0 & 0 & $\ll=$ & 0 & $<=0$ \\
\hline Constraint 3 & 0 & 0 & $<=$ & 0 & $<=0$ \\
\hline Constraint 4 & 0 & 0 & $<=$ & 0 & $<=0$ \\
\hline Constraint 5 & 0 & 0 & $<=$ & 0 & $<=0$
\end{tabular}

Figure 1. Planning of Optimalism Bukit Aradiar Permai Residence

The data that has been inputted appear as Figure 1. The symbols X1 and X2 are two variables that determine the optimum number of units for type 40/120 and type 45/120. In the "Maximize" line, fill in each coefficient value, namely the selling price for each method used or the coefficient value that has been determined in the objective function. In the lines "Constrains 1" to "Constraint 4" each coefficient is entered and replaced according to the name of the constraint function used. After the constraint function and constraint function are entered into the software, then press "SOLUTIONS" to get the optimum number of units and the optimum profit. After that, press "SOLUTIONS" then select ranging to see the results of the sensitivity analysis.

\section{Results and Discussion}

\subsection{Mathematics Modeling}

Modeling is done by determining the objective function and the boundary function as a model that will determine the optimum unit. States that modeling describes the reality in the field in the form of equations and the better the modeling, the better the results: [6]. The determination of the objective function and the boundary function based on the formulation of the decision variables are as follows.

The objective function is a linear mathematical relationship that describes the company's goals: [9]. The equation of the objective function is as equation (1).

$$
Z=510,000,000 C_{1} X_{1}+530,000,000 C_{2} X_{2}
$$

The residential land area of Bukit Aradiar Permai is divided into a plot for a residential area of $24,102 \mathrm{~m}^{2}$ and a plot for public facilities covering an area of $21.438 \mathrm{~m}^{2}$. The types to be built are type 40 and type 45 with a land area of $120 \mathrm{~m}^{2}$ with a land area limit of $24,102 \mathrm{~m}^{2}$. Thus, the mathematical model for the three methods of the effective land area constraint is as equation (2).

$$
120 X_{1}+120 X_{2} \leq 24102
$$

The function of the limit of the people's purchasing power is used to find out the limits of the people who are estimated to be able to buy a house from the price that has been offered: [6]. Data on people's purchasing power is obtained based on finance by knowing the income of the people of Balikpapan City and ownership status so that the following equation (3) is obtained.

$$
X_{1} \leq 9,071 \text { dan } X_{2} \leq 9,071
$$

The consumer interest limit function is obtained from a questionnaire survey. The results of the questionnaire then multiplied by the weight of the choice. The weight of each each choice is Very 
Interested (4), Interested (3), Same (2), Less Interested (1), No Interested (0): [5]. So that the following percentages are obtained based on Table 2 .

Table 1. The results of the questionnaire survey on the function of consumer interest limits

\begin{tabular}{llllllll}
\hline $\begin{array}{l}\text { House } \\
\text { Type }\end{array}$ & $\begin{array}{l}\text { Very } \\
\text { Interested }\end{array}$ & Interested & Same & $\begin{array}{l}\text { Less } \\
\text { interested }\end{array}$ & $\begin{array}{l}\text { Not } \\
\text { Interested }\end{array}$ & Total & Persentage \\
\hline $\mathbf{4 0 / 1 2 0}$ & 64 & 15 & 10 & 2 & 0 & 91 & $49 \%$ \\
$\mathbf{4 5 / 1 2 0}$ & 76 & 12 & 6 & 2 & 0 & 96 & $51 \%$ \\
\hline
\end{tabular}

The equations for type 40/120 and type 45/120 are as fequation (4).

$$
X_{1} \leq 98,4 ; X_{2} \leq 102,4
$$

The function limit of the first year of development for each unit is $20 \%$ development for types 40 and $20 \%$ for the construction of type 45 . This is based on the annual home sales target of $20 \%$ by the Chairman of Balikpapan Real Estate, so that the annual development is $20 \%$ for each type: [2]. The percentage is multiplied by the production cost of each house, so that the following equation is obtained.

$$
\begin{aligned}
& 421,900,861 \times 0.20 X_{1}+434,052,565 \times 0.2 X_{2} \leq 18,000,000,000 \\
& 84,380,172 X_{1}+86,810,513 X_{2} \leq 18,000,000,000 \\
& X_{1}+1.03 X_{2} \leq 213
\end{aligned}
$$

The housing completion time is planned to be completed within 6 years or 288 weeks. The completion of the construction of each type of house is directly proportional to the floor area of the building of each type of house according to: [10], each type has a floor area of $40 \mathrm{~m}^{2}$ and $45 \mathrm{~m}^{2}$. So, we get the following constraint function. Type 40 : Type $45=40: 45=0.89: 1.00$

$$
0.89 X_{1}+X_{2} \leq 288
$$

\subsection{Land Optimization}

Optimization is done by using the QM for Windows program to solve mathematical models and find solutions from several alternative solutions formed by the limiting equations of the

\begin{tabular}{|c|c|c|c|c|c|}
\hline \multicolumn{5}{|c|}{ Linear Programming Results } & $-|\square| x \mid$ \\
\hline \multicolumn{6}{|c|}{ OPTIMASI Solution } \\
\hline & $\mathrm{X} 5$ & $\mathrm{X} 6$ & & RHS & Dual \\
\hline Maximize & $510,000,000$ & $530,000,000$ & & & \\
\hline Tipe $40 / 120$ Tipe $45 / 1201$ & 120 & 120 & $<=$ & 24,102 & 0 \\
\hline Tipe $40 / 120$ Tipe $45 / 1202$ & 1 & 0 & $<-$ & 9,071 & 0 \\
\hline Tipe $40 / 120$ Tipe $45 / 1203$ & 0 & 1 & $<=$ & 9,071 & 0 \\
\hline Tipe $40 / 120$ Tipe $45 / 1204$ & 1 & 1 & $<=$ & 213 & 0 \\
\hline Tipe $40 / 120$ Tipe $45 / 1205$ & 1 & 1 & $\ll$ & 288 & 0 \\
\hline Tipe $40 / 120$ Tipe $45 / 1206$ & 1 & 0 & $<=$ & 98 & $510,000,000$ \\
\hline Tipe 40/120 Tipe $45 / 1207$ & 0 & 1 & $<$ & 102 & $530,000,000$ \\
\hline Solution & 98 & 102 & & $104,456,000,000$ & \\
\hline
\end{tabular}
mathematical model to obtain the optimum value of the objective function. Then the optimization solution is obtained as follows.

The objective and constraint functions are then inputted into the QM for Windows program to obtain optimum units and profits, as shown in Figure 2 below.

Figure 2. The result of optimization QM for Windows 
Figure 2 shows the results of the analysis of the objective function and the boundary function where it is known to maximize profits, the developer must produce 92 units of type 40/120 and 102 units of type 45/120. The combination of the number of units will provide a profit of $\mathrm{Rp}$. $104,456,000,000$.

Sensitivity analysis to observe changes that occur in the coefficients of the objective function and boundary function by analyzing to what extent the coefficients of these functions can change without affecting the optimal solution: [7]. The results of the sensitivity analysis of the objective function and the boundary function are shown in Figure 3.

\begin{tabular}{|c|c|c|c|c|c|}
\hline \multicolumn{6}{|l|}{ 渴 Ranging } \\
\hline \multicolumn{6}{|l|}{ OPTIMASI Solution } \\
\hline Variable & Value & Reduced Cost & Original Val & Lower Bound & Upper Bound \\
\hline $\mathrm{X} 5$ & 98 & 0 & $510,000,000$ & 0 & Infinity \\
\hline \multirow[t]{2}{*}{$\mathrm{X} 6$} & 102 & 0 & $530,000,000$ & 0 & Infinity \\
\hline & Dual Value & Slack/Surplus & Original Val & Lower Bound & Upper Bound \\
\hline Tipe $40 / 120$ Tipe $45 / 1201$ & 0 & 6 & 24,102 & 24,096 & Infinity \\
\hline Tipe $40 / 120$ Tipe $45 / 1202$ & 0 & 8,973 & 9,071 & 98 & Infinity \\
\hline Tipe $40 / 120$ Tipe $45 / 1203$ & 0 & 8,969 & 9,071 & 102 & Infinity \\
\hline Tipe $40 / 120$ Tipe $45 / 1204$ & 0 & 9 & 213 & 204 & Infinity \\
\hline Tipe $40 / 120$ Tipe $45 / 1205$ & 0 & 98 & 288 & 190 & Infinity \\
\hline Tipe $40 / 120$ Tipe $45 / 1206$ & $510,000,000$ & 0 & 98 & 0 & 98 \\
\hline Tipe $40 / 120$ Tipe $45 / 1207$ & $530,000,000$ & 0 & 102 & 0 & 102 \\
\hline
\end{tabular}

Figure 3. The result of sensitivity analysis QM for Windows

Figure 3 shows that type 40/120 and type 45/120 get a value of 98 units and 102 units, respectively, where this value is the optimal result that can be achieved by the developer. The reduced cost value is 0 which means that the use of the two housing unit variables is optimal: [3]. The minimum selling price for type 40/120 is IDR 0 as the lower limit and for type 45/120 the minimum price is IDR 0 for both types, the maximum selling price is unlimited. The value is stated that the coefficient or selling price can be changed according to the recommended lower and upper limits because in the range of coefficient values the objective function does not change the optimal value: [3]. The above analysis states that if the slack/surplus value is more than 0 (zero) and the dual value is equal to 0 (zero), it can be concluded that the resource is in excess. If the dual value is more than 0 (zero) and the slack/surplus value is equal to 0 (zero) then it is called an active constraint function because it fulfills the objective function: [4]. The lowest bound and upper bound values show that these values can be changed according to the recommended upper and lower limits because in this range the coefficient values will not change the optimal value: [3].

\section{Conclussion}

The number of units of each type to obtain optimum income in Bukit Aradiar Permai housing according to the optimization results using the QM for Windows application tool shows 98 units for type 40/120 and 102 units for type 45/120.

\section{Referensi}

[1] Badan Pusat statistik Balikpapan (2018) 'Proyeksi Penduduk Kota Balikpapan Menurut Kecamatan Tahun 2010-2018', Balikpapan, Indonesia.

[2] Edi (2016) 'Harga Rumah di Balikpapan Cenderung Datar Di Akhir 2016', bisnis.com. Available at: https://kalimantan.bisnis.com/.

[3] Hanani, N. (2009) 'Metode Kuantitatif QM For Windows'.

[4] Panggabean, D., Djalal, M. and Santosa (2014) 'Pada Pengolahan Rendang Di Perusahaan,' Jurnal Optimasi Sistem Industri, hal. 427-453. 
[5] Prijowuntato, (2016). 'Evaluasi Pembelajaran'. Universitas Sanata Dharma: Yogyakarta

[6] Purwantini, Ririn. (2015). 'Optimasi Jumlah Unit Rumah Setiap Tipe Pada Proyek Perumahan Green Menganti Regency'. Institut Teknologi Sepuluh Nopember: Surabaya.

[7] Putri, J. N., Yunus, A. and Muawwal, A. (2019) 'Jurnal Ilmu Komputer Kharisma Tech', hal. $1-11$

[8] Sudarsana (2009), 'Optimalisasi Jumlah Tipe Rumah yang akan Dibangun dengan Metode Simpleks pada Proyek Pengembangan Perumahan', Universitas Udayana: Denpasar

[9] Winarsih, A. (2011) 'Optimalisasi Biaya Produksi Pada Cv Jatikarya Embroidery Semarang Dan Simulasinya Dalam Program Solver'. Universitas Negeri Semarang

[10] Warsika, Putu Darma. (2016). 'Perencanaan Komposisi Site Plan Tipe Rumah ada Pembangunan Perumahan Puri Cempaka Mas Dalung'. Universitas Udayana: Bali 